\title{
TWO TECHNICAL AIDS FOR INTERMITTENT STERILE CATHETERISATION
}

\author{
By D. M. Boles, B.Sc., M.B.Bch.(Rand), F.R.C.S.(Glasg.), Sister M. N. Marawu and \\ P. Porteous, M.B.Bch.(Rand), F.R.C.S.(Edin.) \\ Paraplegic Unit, Baragwanath Hospital, fohannesburg, South Africa
}

Abstract. The use of a spray bottle for an antiseptic solution, and a method of attaching the catheter to a disposable urine bag are suggested and discussed.

Key word: Catheterisation.

\section{Introduction}

THE Baragwanath Hospital unit for black paraplegics consists of 34 beds at the present time. Intermittent catheterisation has been sporadically used in the past, but at the beginning of 1977 a team effort was started to introduce this technique on a much larger scale. This attempt met with many problems, not least of which was an inherent fear of self-inflicted injury, the latter being mostly due to primitive ignorance, and was eventually overcome by individual discussion and anatomical instruction carried out in a very informal manner during which, over a period of six months, various patients became sufficiently involved to the extent that they have virtually taken over the instruction of the newer patients. The patients are taught either singly or in groups.

\section{Materials and Methods}

The material and methods used are those which have been accepted worldwide (Guttmann, 1949, I966). During the introduction of these methods it became increasingly obvious that there are too many items for the patient to handle, especially as our cases are only shown twice before being left entirely on their own. The patients are shown how to wash their hands with household soap, insert the catheter (which is kept next to the bed in a vacolitre of dilute Savlon), using KY jelly as the lubricant. We felt it is necessary for our patients to clean the glans each time, and find the added materials-metal kidney bowls and swabsall too involved. It was the sister in charge of the unit who then suggested the use of a small I50 ml spray bottle containing Savlon (Fig. IB) which can be used for two purposes, one, to spray the glans which can then be wiped with one piece of gauze, and two, to flush-through the catheter when drainage is finished. We use one catheter daily per patient.

The author would like to add another useful aid, namely, the catheter should be attached to a plastic disposable urine bag prior to insertion (Fig. IA). This has a number of uses, one, it does away with the infernal noise of kidney bowls crashing to the floor, and two, keeps the patient totally dry. The latter being most important when away from home, as the whole drainage system can be kept rolled up in a plastic bag in the pocket. The third use is that these disposable bags are graded and the patient can record his urinary volumes accurately which helps in deciding the frequency of catheterisation. 


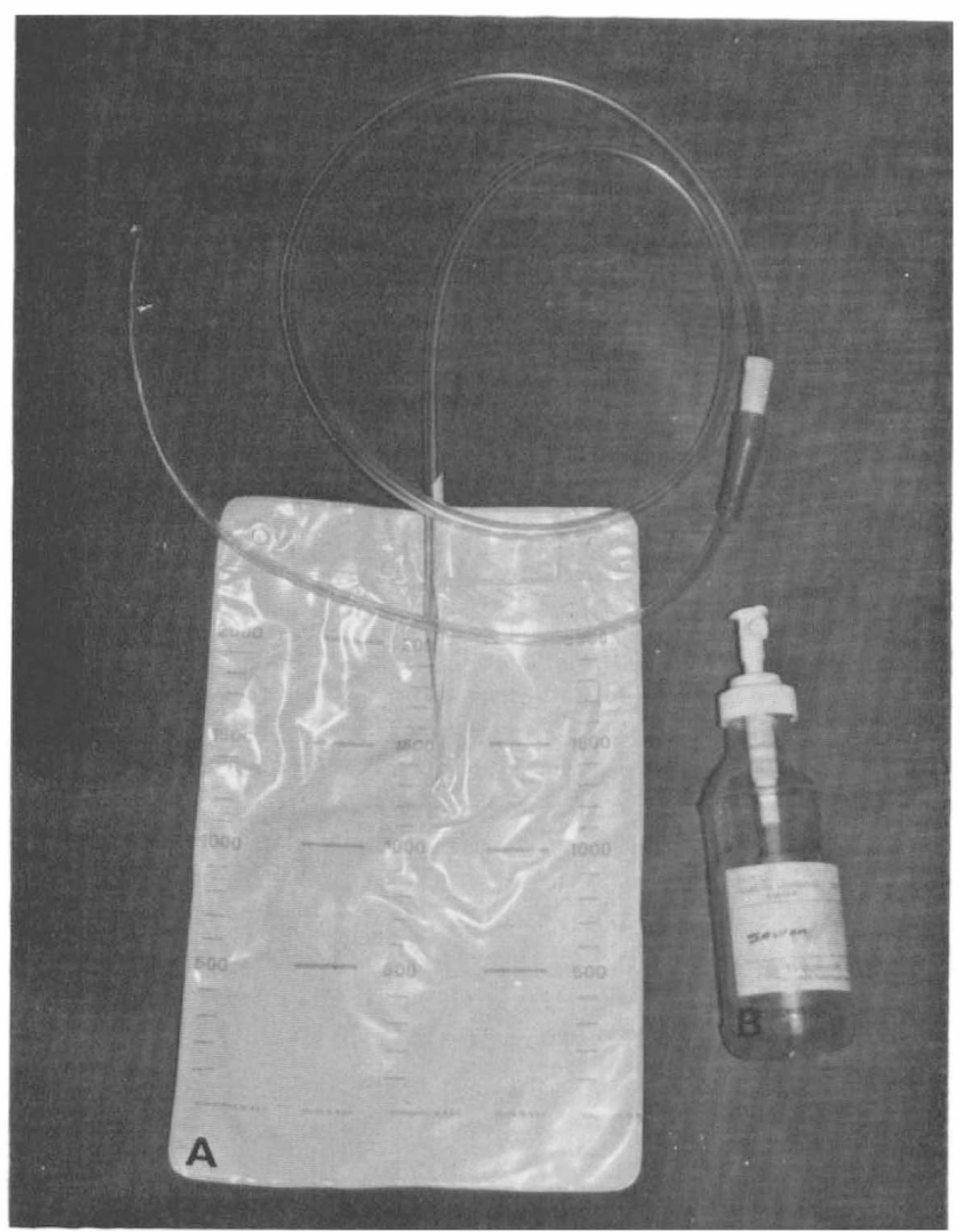

FIG. I

A. Shows disposable, graded, plastic urine bag attached to a disposable plastic catheter prior to insertion. B. I50 ml spray bottle containing dilute Savlon with which the glans is cleaned. The catheter, after it has been used, is flushed through as well.

It is essential that the catheter is inserted to its full length and that when the flow stops it is withdrawn slowly whilst applying constant pressure to the lower abdomen, this ensures complete emptying of the bladder.

\section{Results}

It is early at this stage of our experience to quote results except that the patients response has been remarkable. Some who have been rehabilitated and are living away from the hospital have arrived at the outpatients department asking to be taught the new method and have subsequently come back, having discarded their portable urinals, much happier people. 


\section{Discussion}

The overall success of this technique is without question, although many minor problems are constantly met up with. We have tended to keep our patients on one of the urinary antiseptics adding antibiotics only if the urinary cell count and bacterial count indicate significant infection. In our short experience it would appear that the catheterisation technique should be kept as a relatively sterile procedure, especially whilst in hospital. Using the two techniques described, we are able to keep even the bedridden patients, that is, those who are kept lying prone because of bed sores, on the catheterisation schedule.

\section{Conclusion}

The use of an antiseptic solution in a small bottle makes for a much easier and cleaner procedure, and the attachment of the catheter to a flexible, disposable urinal bag has a number of advantages already mentioned above. This unit is now firmly convinced of the superiority of Intermittent catheterisation over all previous methods, although introducing it in a Black population was not without its setbacks because of overwhelming suspicion. It is hoped that these simple suggestions will be of use to other paraplegic units.

\section{RÉSUMÉ}

L'emploi d'une solution antiseptique dans un petit flacon permet un procédé beaucoup plus facile ainsi que plus propre, et le fait d'attacher la sonde vésicale à une poche à urine, en plastique, flexible et à jeter, offre certains avantages, que nous avons déjà mentionnés plus haut.

Ce service est maintenant convaincu que le sondage vésical intermittent surpasse en efficacité toutes les méthodes employées jusqu'ici, bien que l'introduction de ce procédé auprès d'une population noire extrêmement méfiante à l'égard de celui-ci, ne se soit pas effectuée sans quelques revers.

Nous espérons bien que ces suggestions modestes seront utiles à d'autres services de traitement paraplégique.

\section{ZUSAMMENFASSUNG}

Der Gebrauch einer antiseptischen Lösung in einer kleinen Flasche ermöglicht eine erheblich leichtere und saubere Anwendung. Das Anbringen des Katheders an einen flexiblen und wegwerfbaren Beutel hat, wie oben dargelegt, eine Reihe von Vorzügen. Unsere Abteilung für Querschnittgelähmte ist fest davon überzeugt, dass der periodisch auswechselbare Katheder (intermittent cathederisation) allen andern Methoden überlegen ist-trotz der vehementen, auf Aberglauben beruhenden Ablehnung, mit der die schwarze Bevölkerung dieser Methode bislang begegnet ist. Es ist zu hoffen, dass diese einfachen Vorschläge in der Therapie an Querschnittgelähmten hilfreich sein können.

Acknowledgement. The authors would like to thank Professor R. Lipschitz for his support and encouragement.

\section{REFERENCES}

Comar, A. E. (1959). Brit. F. Urol., 3I, I.

Guttmann, L. (I949). Brit. Surg. Pract., 6, 445.

Guttmann, L. (1958). Modern Trends in Diseases of the Spinal Column. Butterworth, London, p. 258.

Guttmann, L. \& Frankel, H. (1966). Paraplegia, 4, 63.

Lapides, J., Diokono, A. C., Lowe, B. S. \& Kalish, M. D. (1974). F. of Urol., III, I84.

Lipschitz, R. \& van SchalkWYK, J. B. (I962). Medical Proceedings, October, 394.

Prother, G. L. (I959). Surgery in World War II. Office of the Surgeon General, Washington, D.C., Vol. 2, pp. 90 and 99. 